J. Gen. Appl. Microbiol.
Vol. 11, No. 3, 1965

\title{
TAXONOMIC EVALUATION OF NITRATE RESPIRATION AND CARBOHYDRATE FERMENTATION IN AEROBIC BACTERIA
}

\author{
KAZUO KOMAGATA ${ }^{1}$, HIROSHI IIZUKA ${ }^{2}$ and \\ MASAHIRO TAKAHASHI ${ }^{1}$ \\ Received March 26, 1965
}

Several kinds of aerobic bacteria utilize nitrate as hydrogen acceptors in place of molecular oxygen, and grow anaerobically in the presence of nitrate. This respiratory phenomenon is called "nitrate respiration" (1), but it has not been widely used as a criterion for taxonomy. Fermentation of carbohydrates is also a mode of typical anaerobic respiration in microorganisms. HUGH and LEIFSON (2) reported that Gram-negative bacteria should be divided into several groups on the basis of the mode of cleavage of carbohydrates. This proposal was accepted by several workers and employed for the determination of aerobic bacteria $(3,4,5,6)$. In the previous papers $(\boldsymbol{7}, 8)$, it was reported that ability of nitrate respiration and the mode of cleavage of carbohydrates are appropriate as taxonomic features of the genus Pseudomonas. As the mode of respiration is considered to reflect stages in the evolutionary process, the authors were interested in examining the occurrence of nitrate respiration and fermentative cleavage of carbohydrates in aerobic bacteria. This paper presents the distribution of these characteristics and discusses the interrelation of several genera of aerobic bacteria.

\section{MATERIALS AND METHODS}

Microorganisms. Bacteria tested were either freshly isolated from various sources by the authors or obtained from type culture collections, including those of Institute of Applied Microbiology, University of Tokyo and Institute of Food Microbiology, Chiba University, together with Czechoslovak Collection of Microorganisms and American Type Culture Collection. They comprised 440 strains belonging to 126 species and 24 genera. Numbers of bacteria tested are shown in Table 1 ; bacterial genera are listed according to Bergey's Manual of Determinative Bacteriology, 7th edition (9). The taxonomic position of Sporosarcina was decided according to Kocur and MartineC's opinion (10).

Test of nitrate respiration. Anaerobic growth supported by nitrate

1 Central Research Laboratories, Ajinomoto Co., Inc., Kawasaki, Japan.

2 Institute of Applied Microbiology, University of Tokyo, Tokyo. 
Table 1. Numbers of tested bacterial genera and species.

\begin{tabular}{|c|c|c|}
\hline & No. of Species & No. of Strain \\
\hline \multicolumn{3}{|l|}{ Pseudomonadaceae } \\
\hline Pseudomonas & 23 & 178 \\
\hline Xanthomonas & 6 & 8 \\
\hline Protaminobacter & 1 & 2 \\
\hline Aeromonas & 2 & 2 \\
\hline \multicolumn{3}{|l|}{ Spirillaceae } \\
\hline Vibrio & 2 & 2 \\
\hline \multicolumn{3}{|l|}{ Rhizobiaceae } \\
\hline Agrobacterium & 2 & 5 \\
\hline Achromobacteraceae & & \\
\hline Alcaligenes & 4 & 12 \\
\hline Achromobacter & 4 & 5 \\
\hline Flavobacterium & 3 & 4 \\
\hline \multicolumn{3}{|l|}{ Enterobacteriaceae } \\
\hline Escherichia & 2 & 17 \\
\hline Aerobacter & 2 & 10 \\
\hline Erwinia & 2 & 2 \\
\hline Serratia & 1 & 28 \\
\hline Proteus & 4 & 12 \\
\hline \multicolumn{3}{|l|}{ Micrococcaceae } \\
\hline Micrococcus & 7 & 14 \\
\hline Sarcina & 1 & 13 \\
\hline Staphylococcus & 3 & 6 \\
\hline \multicolumn{3}{|l|}{ Brevibacteriaceae } \\
\hline Brevibacterium & 12 & 29 \\
\hline \multicolumn{3}{|l|}{ Corynebacteriaceae } \\
\hline Corynebacterium & 11 & 32 \\
\hline Microbacterium & 2 & 2 \\
\hline Cellulomonas & 5 & 5 \\
\hline Arthrobacter & 9 & 14 \\
\hline \multicolumn{3}{|l|}{ Bacillaceae } \\
\hline Bacillus & 15 & 40 \\
\hline Sporosarcina & 1 & 2 \\
\hline Total & 126 & 440 \\
\hline
\end{tabular}

respiration was tested by the method previously reported by the authors (y). Cells grown on nutrient agar slants for $24 \mathrm{hr}$ were inoculated in nutrient broth containing $1 \% \mathrm{KNO}_{3}$, and the cultures immediately sealed with sterilized liquid paraffin. For control, unsealed cultures in nutrient broth with or without $\mathrm{KNO}_{3}$, and sealed cultures in nutrient broth without 
$\mathrm{KNO}_{3}$ were also employed. Nutrient broth was composed of meat extract, $10 \mathrm{~g}$; peptone, $10 \mathrm{~g} ; \mathrm{NaCl}, 3 \mathrm{~g}$; and distilled water to $1000 \mathrm{ml}$, and $\mathrm{pH}$ adjusted to 7.2. After 1 to 2 days' incubation at $30^{\circ}$, growth, turbidity, and bubbling of gas were observed.

Test of oxidative or fermentative cleavage of carbohydrates. Oxidative or fermentative cleavage of carbohydrates was examined by HugH and Leirson's method (2). Cells grown in nutrient agar slants for $24 \mathrm{hr}$ were stabbed in two tubes of semi-solid agar media containing carbohydrates. After inoculation, one of the tubes was immediately sealed with sterilized liquid paraffin, while the other was left unsealed. The medium was composed of peptone, $2 \mathrm{~g} ; \mathrm{NaCl}, 5 \mathrm{~g} ; \mathrm{K}_{2} \mathrm{HPO}_{4}, 0.3 \mathrm{~g}$; glucose or lactose, $10 \mathrm{~g}$; and distilled water to $1000 \mathrm{ml} ; \mathrm{pH}$ adjusted to 7.2 and colored with bromocresol purple (BCP). After 2 to 5 days' incubation at $30^{\circ}$, growth, turbidity, bubbling of gas and color change of BCP were observed. As the medium was poorly buffered, production of acid could be sharply detected. According to the terminology of HUGH and LeIfson, the occurrence of fermentative cleavage of carbohydrate was recognized when acid was produced in both sealed and unsealed tubes, and the occurrence of oxidative cleavage of carbohydrate was understood when acid production took place only in unsealed tubes.

\section{RESULTS AND DISCUSSION}

As shown in Table 2, ability of nitrate respiration was widely distributed in Gram-negative bacteria, such as Escherichia, Aerobacter, Erwinia, Serratia, Pseudomonas, Alcaligenes, etc. All the Gram-positive bacterial strains which were tested failed to grow anaerobically by nitrate respiration. The strains of Bacillus cereus and $B$. cereus var. mycoides anaerobically produced gas bubbles in nitrate broth in some cases, but visible growth was not apparent. Aerobic bacteria capable of reducing nitrate to nitrite are well known (9), but those capable of growing by nitrate respiration are not as widely found. TAKAHASHI, TANIGUCHI and EGAMI (11) reported that E. coli and S. marcescens could grow anaerobically by nitrate respiration, that the strains of Ps. fluorescens were divided into two groups on the basis of the ability of nitrate respiration, and that $B$. subtilis and $B$. mycoides failed to grow by nitrate respiration. Previously, it was reported that several species of Pseudomonas could grow by nitrate respiration, and that any strains possessing the ability of nitrate respiration were not found in the chromogenic group of genus Pseudomonas $(7,8)$. Tonomura, Futai, Tanabe, and Yamaoka (12) isolated a new monofluoroacetate-decomposing pseudomonad, which was named $P s$. luteochromogenes. It is of interest that this species belongs to the chromogenic group, and possesses the ability of nitrate respiration. As mentioned above, it is remarkable that distribution of ability of nitrate respiration is restricted to Gram-negative bacteria, and that all the strains of 
Table. 2 Distribution of abilities of nitrate respiration and fermentative cleavage of carbohydrates in aerobic bacteria ${ }^{a}$.

\begin{tabular}{|c|c|c|c|c|c|c|}
\hline \multirow{3}{*}{ Organism } & \multirow{3}{*}{$\begin{array}{l}\text { No. of } \\
\text { strains }\end{array}$} & \multirow{3}{*}{$\begin{array}{l}\text { Nitrate } \\
\text { respira- } \\
\text { tion }\end{array}$} & \multicolumn{4}{|c|}{ Cleavage of Carbohydrates } \\
\hline & & & \multicolumn{2}{|c|}{ Glucose } & \multicolumn{2}{|c|}{ Lactose } \\
\hline & & & 0 & $\mathrm{C}$ & 0 & $\mathrm{C}$ \\
\hline \multicolumn{7}{|l|}{ Pseudomonadaceae } \\
\hline \multicolumn{7}{|l|}{ Pseudomonas } \\
\hline \multicolumn{7}{|l|}{ Fluorescent group } \\
\hline Ps. aeruginosa & 17 & + & + & - & - & - \\
\hline Ps. azotoformans (17) & 20 & + & + & - & - & - \\
\hline Ps. chlororaphis & 2 & + & + & - & - & - \\
\hline Ps. schuylkilliensis & 29 & - & - & - & - & - \\
\hline Ps. aureofaciens & 1 & - & + & - & - & - \\
\hline Ps. fragi & 1 & - & $\div$ & - & + & - \\
\hline Ps. cinnamona & 3 & - & + & - & - & - \\
\hline Ps. straminea (17) & 1 & - & $T$ & - & - & - \\
\hline Ps. nitroreducens (18) & 6 & + & + & - & - & - \\
\hline Ps. ovalis & 27 & - & $\div$ & - & - & - \\
\hline Ps. taetrolens & 4 & - & + & - & + & - \\
\hline Ps. fulva (17) & 6 & - & + & - & - & - \\
\hline \multicolumn{7}{|l|}{ Achromogenic group } \\
\hline Ps. putrefaciens & 4 & - & $T$ & - & - & - \\
\hline Ps. maltophila & 5 & - & weakly & - & - & - \\
\hline Ps. stutzeri & 12 & + & + & - & - & - \\
\hline Ps. desmolytica & 12 & - & - & - & - & - \\
\hline Ps. riboflavina & 1 & - & - & - & - & - \\
\hline Ps. iners (19) & 2 & - & - & - & - & - \\
\hline Ps. diminuta & 1 & - & - & - & - & - \\
\hline \multicolumn{7}{|l|}{ Chromogenic group } \\
\hline Ps. melanogenum & 6 & - & + & - & - & - \\
\hline Ps. lacunogenes & 12 & - & + & - & - & - \\
\hline Ps. ochracea & 1 & - & + & - & - & - \\
\hline Ps. luteochromogenes (12) & 1 & + & + & - & - & - \\
\hline
\end{tabular}

(to be continued)

O: Open, tubes are unsealed.

+ : Positive reaction.

C: Closed, tubes are sealed.

a Figures (non italisized) in parentheses indicate the number of strains which gave positive reaction.

$b$ Of 11 strains, 6 produced acid from lactose weakly.

c Of 12 strains, 6 produced acid weakly. 
Table 2 (continued)

\begin{tabular}{|c|c|c|c|c|c|c|}
\hline \multirow{3}{*}{ Organism } & \multirow{3}{*}{$\begin{array}{l}\text { No. of } \\
\text { strains }\end{array}$} & \multirow{3}{*}{$\begin{array}{r}\text { Nitrate } \\
\text { respira- } \\
\text { tion }\end{array}$} & \multicolumn{4}{|c|}{ Cleavage of Carbohydrates } \\
\hline & & & \multicolumn{2}{|c|}{ Glucose } & \multicolumn{2}{|c|}{ Lactose } \\
\hline & & & 0 & $\mathrm{C}$ & $\mathrm{O}$ & $\mathrm{C}$ \\
\hline \multicolumn{7}{|l|}{ Pseudomonadaceae } \\
\hline \multicolumn{7}{|l|}{ Xanthomonas } \\
\hline$X$. oryzae & 2 & - & + & - & - & - \\
\hline$X$. pruni & 2 & - & + & - & - & - \\
\hline$X$. begoniae & 1 & - & + & - & - & - \\
\hline$X$. campestris & 1 & - & + & - & - & - \\
\hline$X$. citri & 1 & - & + & - & - & - \\
\hline X. malvacearum & 1 & - & - & - & - & - \\
\hline \multicolumn{7}{|l|}{ Protaminobacter } \\
\hline P. alboflavum & 1 & - & - & - & - & - \\
\hline \multicolumn{7}{|l|}{ Aeromonas } \\
\hline A. hydrophila & 1 & ? & + & + & + & + \\
\hline A. punctata & 1 & $?$ & + & + & + & + \\
\hline \multicolumn{7}{|l|}{ Spirillaceae } \\
\hline \multicolumn{7}{|l|}{ Vibrio } \\
\hline V. metschnikovii & 1 & - & + & + & - & - \\
\hline$V$. tyrogenes & 1 & - & + & + & - & - \\
\hline \multicolumn{7}{|l|}{ Rhizobiaceae } \\
\hline \multicolumn{7}{|l|}{ Agrobacterium } \\
\hline A. tumefaciens & 3 & $+(2)^{a}$ & $+(1)$ & - & - & - \\
\hline A. radiobacter & 2 & $+(1)$ & $+(1)$ & - & - & - \\
\hline \multicolumn{7}{|l|}{ Achromobacteraceae } \\
\hline \multicolumn{7}{|l|}{ Alcaligenes } \\
\hline A. faecalis & 7 & + & - & - & - & - \\
\hline A. viscolactis & 2 & - & - & - & - & - \\
\hline A. marshallii & 1 & - & - & - & - & - \\
\hline A. metalcaligenes & 2 & - & - & - & - & - \\
\hline \multicolumn{7}{|l|}{ Achromobacter } \\
\hline A. liquidum & 1 & - & - & - & - & - \\
\hline A. cycloclastus & 1 & - & - & - & - & - \\
\hline A. delicatulus & 1 & - & + & + & - & - \\
\hline A. delmarvae & 2 & - & + & - & - & - \\
\hline \multicolumn{7}{|l|}{ Flavobacterium } \\
\hline F. lutescens & 2 & - & - & - & - & - \\
\hline
\end{tabular}

(to be continued) 
Table 2 (continued)

\begin{tabular}{|c|c|c|c|c|c|c|}
\hline \multirow{3}{*}{ Organism } & \multirow{3}{*}{$\begin{array}{l}\text { No. of } \\
\text { strains }\end{array}$} & \multirow{3}{*}{$\begin{array}{r}\text { Nitrate } \\
\text { respira- } \\
\text { tion }\end{array}$} & \multicolumn{4}{|c|}{ Cleavage of Carbohydrates } \\
\hline & & & \multicolumn{2}{|c|}{ Glucose } & \multicolumn{2}{|c|}{ Lactose } \\
\hline & & & $\mathrm{O}$ & $\mathrm{C}$ & 0 & $\mathrm{C}$ \\
\hline$F$. solare & 1 & - & - & - & - & - \\
\hline$F \cdot$ ferrugineum & 3 & - & + & - & + & - \\
\hline \multicolumn{7}{|l|}{ Enterobacteriaceae } \\
\hline \multicolumn{7}{|l|}{ Escherichia } \\
\hline E. coli & 16 & + & + & + & + & + \\
\hline E. freundii & 1 & t. & + & $\div$ & + & + \\
\hline \multicolumn{7}{|l|}{ Aerobacter } \\
\hline A. aerogenes & 6 & + & + & + & + & + \\
\hline A. cloacae & 4 & + & $+\frac{1}{+}$ & + & + & + \\
\hline \multicolumn{7}{|l|}{ Erwinia } \\
\hline E. carotovora & 1 & + & + & + & + & + \\
\hline E. aroideae & 1 & + & $\div$ & + & + & + \\
\hline \multicolumn{7}{|l|}{ Serratia } \\
\hline S. marcescens & 28 & + & + & + & $+(11)^{b}$ & $+(12)^{c}$ \\
\hline \multicolumn{7}{|l|}{ Proteus } \\
\hline P. vulgaris & 4 & + & + & + & + & + \\
\hline P. morganii & 2 & + & + & + & $+(1)$ & $+(1)$ \\
\hline P. mirabilis & 3 & + & + & + & + & + \\
\hline$P$. rettgeri & 3 & + & + & + & $+(2)$ & + \\
\hline \multicolumn{7}{|l|}{ Micrococcaceae } \\
\hline \multicolumn{7}{|l|}{ Micrococcus } \\
\hline M. luteus & 2 & - & - & - & - & - \\
\hline$M$. varians & 3 & - & + & + & - & - \\
\hline$M$. roseus & 1 & - & - & - & - & - \\
\hline M. candidus & 2 & - & + & + & + & + \\
\hline M. rubens & 1 & - & - & - & - & - \\
\hline M. conglomeratus & 4 & - & + & + & + & $+(2)$ \\
\hline M. caseolyticus & 1 & - & + & + & - & - \\
\hline \multicolumn{7}{|l|}{ Sarcina } \\
\hline S. lutea & 1 & - & - & - & - & - \\
\hline S. lutes sub. sp. flava & 12 & - & - & - & - & - \\
\hline \multicolumn{7}{|l|}{ Staphylococcus } \\
\hline S. aureus & 4 & - & + & + & + & + \\
\hline S. citreus & 1 & - & + & + & + & + \\
\hline
\end{tabular}

(to be continued) 
Table 2 (continued)

\begin{tabular}{|c|c|c|c|c|c|c|}
\hline \multirow{3}{*}{ Organism } & \multirow{3}{*}{$\begin{array}{l}\text { No. of } \\
\text { strains }\end{array}$} & \multirow{3}{*}{$\begin{array}{l}\text { Nitrate } \\
\text { respira- } \\
\text { tion }\end{array}$} & \multicolumn{4}{|c|}{ Cleavage of Carbohydrates } \\
\hline & & & \multicolumn{2}{|c|}{ Glucose } & \multicolumn{2}{|c|}{ Lactose } \\
\hline & & & 0 & $\mathrm{C}$ & 0 & $\mathrm{C}$ \\
\hline S. epidermides & 1 & - & + & + & + & + \\
\hline \multicolumn{7}{|l|}{ Brevibacteriaceae } \\
\hline \multicolumn{7}{|l|}{ Brevibacterium } \\
\hline B. albidum (20) & 1 & - & - & - & - & - \\
\hline B. ammoniagenes & 2 & - & $+(1)$ & - & - & - \\
\hline B. citreum (20) & 2 & - & - & - & - & - \\
\hline B. helvolum & 4 & - & + & $?$ & - & - \\
\hline B. imperiale & 1 & - & + & + & + & + \\
\hline B. incertum & 1 & - & + & + & + & + \\
\hline B. lipolyticum & 2 & - & - & - & - & - \\
\hline$B$. linens & 5 & - & - & - & - & - \\
\hline B. luteum (20) & 1 & - & - & - & - & - \\
\hline B. pusillum (21) & 2 & - & + & + & - & - \\
\hline B. stationis & 1 & - & + & + & - & - \\
\hline B. sulfureum & 1 & - & - & - & - & - \\
\hline B. testaceum (20) & 5 & - & + & + & - & - \\
\hline B. vitarumen & 1 & - & + & + & - & - \\
\hline \multicolumn{7}{|l|}{ Corynebacteriaceae } \\
\hline \multicolumn{7}{|l|}{ Corynebacterium } \\
\hline C. pseudodiphtheriticum & 2 & - & - & - & - & - \\
\hline C. xerosis & 2 & - & + & + & - & - \\
\hline C. equi & 3 & - & + & - & - & - \\
\hline C. renale & 1 & - & - & - & - & - \\
\hline C. bovis & 1 & - & - & - & - & - \\
\hline C. fasciens & 2 & - & + & - & - & - \\
\hline C. flaccumfaciens & 3 & - & + & - & - & - \\
\hline C. hoagi & 1 & - & + & - & - & - \\
\hline C. insidiosum & 1 & - & - & - & - & - \\
\hline C. michiganense & 5 & - & - & - & - & - \\
\hline C. hydrocarboclastus (18) & 11 & - & + & - & - & - \\
\hline \multicolumn{7}{|l|}{ Microbacterium } \\
\hline M. flavum & 1 & - & + & + & - & - \\
\hline M. lacticum & 1 & - & + & + & + & + \\
\hline \multicolumn{7}{|l|}{ Cellulomonas } \\
\hline C. biazotea & 1 & - & + & + & + & + \\
\hline
\end{tabular}

(to be continued) 
Table 2 (continued)

\begin{tabular}{|c|c|c|c|c|c|c|}
\hline \multirow{3}{*}{ Organism } & \multirow{3}{*}{$\begin{array}{l}\text { No. of } \\
\text { strains }\end{array}$} & \multirow{3}{*}{$\begin{array}{c}\text { Nitrate } \\
\text { respira- } \\
\text { tion }\end{array}$} & \multicolumn{4}{|c|}{ Cleavage of Carbohydrates } \\
\hline & & & \multicolumn{2}{|c|}{ Glucose } & \multicolumn{2}{|c|}{ Lactose } \\
\hline & & & $\mathrm{O}$ & $\mathrm{C}$ & $\mathrm{O}$ & $\mathrm{C}$ \\
\hline C. fimi & 1 & - & - & - & - & - \\
\hline C. flavigena & 1 & - & + & + & + & + \\
\hline C. gelida & 1 & - & + & + & + & + \\
\hline C. $u d a$ & 1 & - & + & + & + & - \\
\hline \multicolumn{7}{|l|}{ Arthrobacter } \\
\hline A. globiformis & 1 & - & - & - & - & - \\
\hline A. pascens & 1 & - & + & - & - & - \\
\hline A. simplex & 1 & - & - & - & - & - \\
\hline A. aurescens & 1 & - & + & - & - & - \\
\hline A. ureafaciens & 3 & - & + & - & - & - \\
\hline A. tumescens & 3 & - & + & - & - & - \\
\hline A. citreus & 2 & - & + & + & - & - \\
\hline A. atrocyaneus & 1 & - & + & - & - & - \\
\hline A. variabilis & 1 & - & + & - & - & - \\
\hline \multirow{2}{*}{\multicolumn{7}{|c|}{$\begin{array}{c}\text { Bacillaceae } \\
\text { Bacillus }\end{array}$}} \\
\hline & & & & & & \\
\hline B. megaterium & 6 & - & + & + & - & - \\
\hline B. cereus & 5 & $-?$ & + & + & - & - \\
\hline B. cereus var. mycoides & 2 & $-?$ & + & + & - & - \\
\hline B. subtilis & 10 & - & + & + & - & - \\
\hline B. pumilus & 1 & - & + & + & - & - \\
\hline B. coagulans & 4 & - & + & + & + & + \\
\hline B. firmus & 1 & - & - & - & - & - \\
\hline B. polymyxa & 1 & - & + & + & + & + \\
\hline B. macerans & 2 & - & + & + & + & + \\
\hline B. circulans & 3 & - & + & + & + & + \\
\hline B. alvei & 1 & - & + & + & - & - \\
\hline B. brevis & 1 & - & - & - & - & - \\
\hline B. sphericus & 1 & - & + & - & - & - \\
\hline B. aneurinolyticus & 1 & - & - & - & - & - \\
\hline B. thiaminolyticus & 1 & - & - & - & - & - \\
\hline \multicolumn{7}{|l|}{ Sporosarcina } \\
\hline S. ureae & 2 & - & - & - & - & - \\
\hline
\end{tabular}


Gram-positive bacteria tested failed to grow anaerobically by nitrate respiration. It is believed that the mode of nitrate respiration is more primitive than that of aerobic cytochrome respiration from the view-point of evolution (13). From this point of view, it seems likely that Gram-positive bacteria are more highly developed microorganisms than Gram-negative bacteria.

The fermentative production of acid from glucose was widely recognized among the aerobic bacteria. Generally, the members of Enterobacteriaceae, especially Escherichia and Aerobacter, produced acid and gas powerfully from glucose, and the other strains belonging to Gram-positive group, such as Micrococcus, Brevibacterium, Microbacterium, Bacillus, etc., produced acid weakly or moderately, but no gas, from glucose. The members of Pseudomonas produced acid only oxidatively, but no gas, from glucose. The strains producing acid from lactose were almost limited to the members of Enterobacteriaceae, but a few other species belonging to Cellulomonas, Brevibacterium, Microbacterium, etc. weakly produced acid from lactose. Furthermore, it is of great interest that the bacteria equipped with both the abilities of nitrate respiration and carbohydrate fermentation are limited to the members of Enterobacteriaceae. From these facts, the members of this family can be easily distinguished from the other bacteria by testing both the abilities.

Table 3. Relationship between flagellar arrangement and abilities of nitrate respiration and fermentative cleavage of carbohydrates in aerobic Gram-negative bacteria.

\begin{tabular}{|c|c|c|c|}
\hline & Polar & Peritrichous & Non-motile \\
\hline \multirow{9}{*}{ 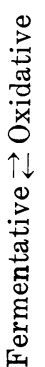 } & Pseudomonas & & \\
\hline & fluorescent group ${ }^{a}$ & & \\
\hline & & Agrobacterium ${ }^{a}$ & \\
\hline & achromogenic group ${ }^{a}$ & Alcaligenes $^{a}$ & Alcaligenes \\
\hline & & Achromobacter & Achromobacter ${ }^{b c}$ \\
\hline & chromogenic group ${ }^{a}$ & Flavobacterium & Flavobacterium \\
\hline & & Serratia ${ }^{a b}$ & Serratia ${ }^{a b}$ \\
\hline & Aeromonas $^{b}$ & Aerobacter ${ }^{a b}$ & Aerobacter ${ }^{a b}$ \\
\hline & & Escherichia ${ }^{a b}$ & Escherichia ${ }^{a b}$ \\
\hline
\end{tabular}

a Nitrate respiration-positive strains are included in the genus.

$b$ Fermenative cleavage of carbohydrate-positive strains are included in the genus.

$c$ Activity of fermentative cleavage of carbohydrate is weak.

As shown in Table 3, these findings agree well with the interrelation of the aerobic Gram-negative bacteria as was previously proposed by the authors $(14,15)$ on the basis of nutritional requirements and distribution of nucleoside phosphotransferase. The oxidative and polary flagellated becteria, such as the fluorescent group of Pseudomonas $(7,8)$, contrast with fermentative and polarly flagellated bacteria, such as Aeromonas, with respect 
to the mode of respiration. Polarly flagellated bacteria, such as the achromogenic group of Pseudomonas $(7,8)$, seem likely to be similar to peritrichously flagellated or non-motile Alcaligenes or Achromobacter with respect to physiological characteristics. These results may stress a difference between Pseudomonadaceae and Enterobacteriaceae. In Krassilnikov's Manual (16), genus Bacterium includes the genera of Escherichia, Aerobacter, Achromobacter, etc. of the nomenclature of Bergey's Manual. However, as described above, it is more appropriate to consider that Bacterium may be divided into several genera on the basis of physiological and biochemical characteristics.

\section{SUMMARY}

The distribution of abilities of nitrate respiration and mode of cleavage of carbohydrates (oxidative or fermentative) were examined on the aerobic bacteria. The ability of nitrate respiration was only found in Gramnegative bacteria, such as Escherichia, Aerobacter, Erwinia, Serratia, Pseudomonas, Alcaligenes, etc., and was not found in the Gram-positive bacteria tested. The ability of fermentative cleavage of carbohydrates was widely distributed in aerobic bacteria, especially in Enterobacteriaceae. Meanwhile, Pseudomonas produced acid only oxidatively from glucose. As the members of Enterobacteriaceae were equipped with both the abilities of nitrate respiration and fermentative cleavage of carbohydrates, those of this family could be easily distinguished from the members of other families by testing both the abilities. The interrelation among the aerobic bacteria was discussed on the basis of the ability of nitrate respiration and the mode of cleavage of carbohydrates.

The authors wish to thank Dr. Aiso, Institute of Food Microbiology, Chiba University, and Dr. M. Kocur, Czechoslovak Collection of Microorganisms, for supplying the bacterial cultures, and also Miss N. Okada and Mr. Y. Tamagawa of this laboratory for their technical assistance.

\section{REFERENCES}

(1) R. SATo: Inorganic Nitrogen Metabolism, edited by W. D. McElroy, p. 163, Johns Hopkins Press, Baltimore (1956).

(2) R. Hugh and E. Leifson: J. Bacteriol., 66, 24 (1953).

(3) R. Buttiaux and P. Gagnon: Ann. Inst. Pasteur Lille, 10, 121 (1958-1959).

(4) M. Véron and R. Chatelain: Ann. Inst. Pasteur., 99, 253 (1960).

(5) J. M. Shewan, G. Hobbs and W. Hodgkiss: J. Appl. Bacteriol., 23, 379 (1960).

(6) K. Klinge: J. Appl. Bacteriol., 23, 442 (1960).

(7) H. Iizuka and K. Komagata: J. Gen. Appl. Microbiol., 9, 73 (1963).

(8) H. Iizuka and K. Komagata: J. Gen. Appl. Microbiol., 9, 83 (1963).

(9) R. S. Breed, E. G. D. Murray and N. R. Smith: Bergey's Manual of Determinative Bacteriology, 7th edition. Williams and Wilkins, Baltimore (1957). 
(10) M. Kocur and T. Martinec: Intern. Bull. Bacteriol. Nomencl. Taxon., 13, 201 (1963).

(11) H. Takahashi, S. Taniguchi and F. Egami: J. Biochem. (Tokyo)., 43, 223 (1956).

(12) K. Tonomura, F. Futai, O. Tanabe and T. Yamaoka: Agr. Biol., Chem., 29, 124 (1965).

(13) T. Yamanaka, A. Ota, S. Kijimoto, K. Miki and K. Okunuki: Symposia on Enzyme Chemistry, No. 17, p. 123. Nanko-do, Tokyo (1962) in Japanese.

(14) K. Komagata: J. Gen. Appl. Microbiol., 7, 282 (1961).

(15) K. Mitsugi, K. Komagata, M. Takahashi, H. Iizuka and K. Katagiri: Agr. Biol. Chem., 28, 586 (1964).

(16) N. A. Krassilnikov: Diagnostik der Bakterien und Actinomyceten. Gustav Fischer, Jena. (1959)

(17) H. Iizuka and K. Komagata: J. Agr. Chem. Soc. Japan., 37, 137 (1963) in Japanese with English description of bacterium.

(18) H. Iizuka and K. Komagata: J. Gen. Appl. Microbiol., 10, 207 (1964).

(19) H. Iizuka and K. Komagata: J. Gen. Appl. Microbiol., 10, 223 (1964).

(20) K. Komagata and H. Irzuka: J. Agr. Chem. Soc. Japan., 38, 496 (1964) in Japanese with English description of bacterium.

(21) H. Iizuka and K. Komagata: J. Gen. Appl. Microbiol., 11, 1 (1965). 